\title{
PENILAIAN KINERJA PEMASOK KAYU DENGAN MENGGUNAKAN PENDEKATAN METODE ANALYTICAL HIERARCHY PROCESS (AHP)
}

\author{
Dian Eko Hari Purnomo ${ }^{\text {1) }}$, Alfani Risman Nugroho ${ }^{2)}$ \\ ${ }^{1,2)}$ Politeknik Industri Furnitur dan Pengolahan Kayu \\ Email: dian.eko.hari.p@gmail.com
}

\begin{abstract}
ABSTRAK
Penilaian kinerja pemasok merupakan keputusan yang penting dalam suatu perusahaan, karena akan meningkatkan daya saing perusahaan dalam menghadapi persaingan bisnis yang sangat kompetitif. CV. Rimba Sentosa sedang melakukan pemilihan supplier yang akan memasok bahan baku kayu mahoni dengan lima pemasok, yaitu Manggala Jati, UD. Jati Mukti, Toko Kayu Jati"Mukti", Gunung Hijau, dan Indah Sentosa. Dalam penelitian ini penilaian kinerja pemasok terbaik menggunakan metode Analytical Hierarchy Process (AHP). Metode ini didasarkan pada konsep perbandingan berpasangan untuk setiap hirarki yang ada pada struktur hirarki yang ada. Kriteria yang digunakan dalam pemilihan ini ada 3 kriteria dan 6 sub kriteria yang mendukung setiap kriteria. Kriteria-kriteria yang dapat digunakan untuk penilaian kinerja pemasok adalah waktu, kualitas, dan harga. Sub kriteria yang dapat digunakan dalam untuk penilaian kinerja pemasok adalah pengiriman tepat waktu, lead time, spesifikasi bahan baku, jumlah bahan baku, harga pembelian bahan baku, dan biaya transportasi. Berdasarkan perhitungan dengan menggunakan metode AHP, maka pemasok yang mempunyai nilai terbaik adalah pemasok "Indah Sentosa", yang mana nilainya adalah 0,344 atau $34,420 \%$.
\end{abstract}

Kata kunci: Penilaian Kinerja Pemasok, AHP

\section{Pendahuluan}

Penilaian kinerja pemasok merupakan salah satu hal penting dalam aktivitas pembelian dan pembelian merupakan aktivitas penting bagi perusahaan. Pembelian bahan baku, dan persediaan merepresentasikan porsi yang cukup besar pada produk jadi. Diberbagai perusahaan manufaktur, persentase ongkos material bisa mencapai antara 40\%-70\% dari ongkos sebuah produk jadi [1]. Dalam mengambil keputusan untuk memilih pemasok, pengambil keputusan membutuhkan alat analisis yang memungkinkan mereka untuk memecahkan masalah yang bersifat kompleks sehingga keputusan yang diambil optimal.

Persaingan antar perusahaan dewasa ini semakin ketat, hal ini didukung oleh perkembangan teknologi yang semakin maju dan berkembang. Perkembangan dan riset yang dilakukan oleh perusahaan mulai dari masalah perencanaan produksi, proses pengadaan bahan baku, perancangan produk baru, bahkan sampai analisa keuangan. Berdasarkan hal tersebut maka sebuah perusahaan sangat membutuhkan efisiensi dari berbagai segi guna memaksimalkan output baik produk maupun keuntungan dengan menekan biaya serendah mungkin.

Salah satu hal yang menunjang keberhasilan proses pengadaan dalam perusahaan adalah pemilihan pemasok atau penilaian kinerja pemasok material yang tepat [2]. CV. Rimba Sentosa adalah perusahaan yang bergerak dalam bidang furniture export, dalam pembuatan produknya menggunakan dua jenis bahan baku yaitu kayu akasia dan kayu jati. Untuk memenuhi bahan baku tersebut CV. Rimba Sentosa bekerjasama dengan pemasok. Dari hasil observasi diketahui bahwa CV. Rimba Sentosa bekerjasama dengan pemasok Manggala Jati, UD. Mukti Jati, Toko Kayu "Mukti", Danang, Gunung Hijau, Indah Sentosa. Dalam pemilihan pemasok yang dilakukan oleh CV. Rimba sebelumnya hanya berdasar pada intuisi para pengambil keputusan dan belum ada metode sebelumnya. Dengan adanya penelitian ini diharapkan dapat memberi masukan yang tepat dalam hal pemilihan pemasok atau penilaian kinerja pemasok.

Pemilihan pemasok atau penilaian kinerja pemasok yang baik akan melancarkan seluruh proses produksi perusahaan, menghasilkan produk jadi yang berkualitas dan menghasilkan keuntungan bagi perusahaan. Pemilihan pemasok atau penilaian kinerja pemasok yang salah dapat memperburuk posisi seluruh rantai suplai, keuangan dan operasional. Pemilihan pemasok atau penilaian kinerja pemasok yang tepat secara signifikan akan mengurangi biaya pembelian material dan meningkatkan daya saing perusahaan [3]. Penilaian kinerja pemasok telah dilakukan oleh beberapa peneliti sebelumnya. Adapun jenis pasokan sebagai bahan baku kayu pengambilan keputusan dalam studi 


\section{KAIZEN : MANAGEMENT SYSTEMS \& INDUSTRIAL ENGINEERING JOURNAL VOL. 3 NO. 2 TEKNIK INDUSTRI UNIVERSITAS PGRI MADIUN}

kasus ini menggunakan Metode Fuzzy AHP dan Fuzzy TOPSIS. Dalam proses pembobotannya menggunakan Metode Fuzzy AHP. Sedangkan untuk proses penilain alternatifnya menggunakan metode Fuzzy TOPSIS [4]. Metode pemilihan pemasok dapat dilakukan dengan Metode Simple Additive Weighting (SAW). Metode tersebut mempunyai kelemahan dalam mengatasi faktor ketidakpastian dalam pengambilan keputusan dan lebih mengutamakan pada jenis kriteria yang bersifat cost dan benefit [5]. Metode lain seperti metode Fuzzy dan Simple Additive Weighting (SAW) digunakan dalam pemilihan pemasok. Dimana Fuzzy digunakan untuk menentukan pemasok yang dipilih dan Fuzzy Simple Additive Weighting (SAW) sebagai pembobotan kriteria, karena Simple Additive Weighting (SAW) mempunyai kelemahan dalam mengatasi faktor ketidakpastian dalam pengambilan keputusan [6]. Alternatif lain seperti Metode Analitycal Hierarchy Process (AHP). Dalam proses pembobotannya dan proses penilain alternatifnya menggunakan Metode Analitycal Hierarchy Process (AHP) [7]. Beberapa penelitian terdahulu mengunakan metode Promethee dalam pemilihan pemasok. Akan tetapi dalam pembobotannya menggunakan NGT (Nominal Group Teknologi) [8].

Berdasarkan uraian di atas, pemilihan pemasok atau penilaian kinerja pemasok adalah aktivitas penting didalam perusahaan. Pemilihan pemasok atau penilaian kinerja pemasok yang salah akan memberikan pasokan bahan baku kayu yang kurang berkualitas. Terdapat juga kelemahan dalam pemilihan pemasok yang dilakukan oleh CV. Rimba Sentosa yaitu pengambil keputusan menilai hanya berdasarkan pada harga yang ditawarkan dan kualitas yang dimiliki bahan baku secara subyektif. Oleh karena itu, penelitian ini bertujuan untuk melakukan pemilihan pemasok atau penilaian kinerja pemasok dengan pertimbangan yang lebih komprehensif dan obyektif. Dalam penelitian ini akan menggunakan metode Analytical Hierarchy Process (AHP) untuk pemilihan pemasok yang optimal. Dengan adanya hal tersebut pihak manajemen bisa menjadikan salah satu acuan dalam pemilihan pemasok atau penilaian kinerja pemasok bahan baku kayu.

\section{Metode Penelitian}

Tahapan-tahapan yang akan dilakukan dalam penelitian dapat dilakukan dengan beberapa tahapan yaitu :

1. Studi Pustaka

Pemahaman terhadap berbagai landasan teori yang terkait dengan pelaksanaan penelitian dilakukan pada tahap ini. Penelaahan terhadap literatur yang terkait dengan tujuan penelitian antara lain prinsip-prinsip sistem pendukung keputusan, cara kerja metode $A H P$ dan penelitian terkait baik melalui buku-buku, jurnal, dan situs internet yang ada. Sehingga diperoleh suatu pemahaman terhadap tahapan-tahapan dalam penyelesaian permasalahan peneitian.

2. Pengumpulan Data

Pada tahap ini, dilakukan pengamatan secara langsung ke obyek penelitian untuk mendapatkan informasi kriteria dan subkriteria apa yang paling berpengaruh dalam pemilihan lokasi, dari manajer dan 2 staf tenaga kerja bepengalaman menggunakan kuisioner. Selain itu pada tahapan pengumpulan data ini peneliti melakukan wawancara untuk menganalisa informasi yang berkaitan dengan permasalahan yang terjadi di CV. Rimba Sentosa. Hal ini bertujuan memperoleh informasi lebih fokus dan mendalam mengenai permasalahan yang terjadi.

3. Pengolahan Data

Dalam pengolahan data, dilakukan beberapa langkah berikut:

a. Penentuan Matriks Perbadingan Berpasangan

Elemen-elemen yang disusun secara hierarkis ditentukan prioritasnya dengan mensintesis pertimbangan kita terhadap elemen-elemen menurut relatif pentingnya atau yang lebih disukai. Untuk hal tersebut kita harus melakukan perbandingan berpasangan antara elemen-elemen tersebut dan melakukan suatu pembobotan dan penjumlahan untuk menghasilkan satu bilangan tunggal yang menunjukkan prioritas setiap elemen dimaksud.

b. Normalisasi Matriks Perbandingan Berpsangan Hingga didapatkan seluruh data yang normal.

c. Uji konsistensi Logis

Konsistensi logis diperlukan dalam menetapkan prioritas untuk elemen-elemen agar memperoleh hasil yang akurat dalam dunia nyata. Prosedur AHP ini mengukur konsistensi secara menyeluruh dari berbagai pertimbangan kita dengan Rasio Konsistensi nilainya maksimum harus 10\% atau kurang. 


\section{KAIZEN : MANAGEMENT SYSTEMS \& INDUSTRIAL ENGINEERING JOURNAL VOL. 3 NO. 2 TEKNIK INDUSTRI UNIVERSITAS PGRI MADIUN}

4. Analisis Data

Selanjutnya hasil dari pengolahan data primer dan sekunder melalui metode AHP akan dianalisis lebih lanjut secara deskriptif berdasarkan informasi yang penulis peroleh dari hasil observasi dan wawancara langsung dengan para narasumber.

5. Kesimpulan

Membuat kesimpulan serta saran dari keseluruhan penelitian yang telah dilakukan.

\section{Hasil dan Pembahasan}

Kriteria dalam penelitian ini menggunakan pendekatan penelitian terdahulu dan wawancara dengan pihak perusahaan Hasil yang diperoleh berupa daftar kriteria pada Tabel 1, daftar sub kriteria pada Tabel 2, daftar alternatif pada Tabel 3 dan struktur hirarki pemasok pada Gambar 1.

Tabel 1. Daftar Kriteria

\begin{tabular}{|c|c|l|}
\hline No & Kriteria & \multicolumn{1}{|c|}{ Keterangan } \\
\hline 1 & Waktu & $\begin{array}{l}\text { Kriteria ini terkait dengan semakin cepat atau semakin singkat } \\
\text { waktu pengiriman maka semakin baik, sedangkan semakin lama } \\
\text { atau semakin lambat waktu pengiriman maka semakin tidak baik. }\end{array}$ \\
\hline 2 & Kualitas & $\begin{array}{l}\text { Kriteria ini terkait dengan semakin tinggi kualitas bahan baku maka } \\
\text { semakin baik, sedangkan semakin rendah kualitas bahan baku maka } \\
\text { semakin tidak baik. }\end{array}$ \\
\hline 3 & Harga & $\begin{array}{l}\text { Kriteria ini terkait dengan semakin tinggi harga bahan baku maka } \\
\text { semakin tidak dipilih, sedangkan semakin rendah harga bahan baku } \\
\text { maka semakin dipilih. }\end{array}$ \\
\hline
\end{tabular}

Tabel 2. Daftar Sub Kriteria

\begin{tabular}{|c|c|c|c|}
\hline No & Kriteria & Sub Kriteria & Keterangan \\
\hline \multirow{2}{*}{1} & \multirow{2}{*}{ Waktu } & $\begin{array}{l}\text { Pengiriman } \\
\text { Tepat Waktu }\end{array}$ & $\begin{array}{l}\text { Sub riteria ini terkait dengan semakin tepat waktu pengiriman } \\
\text { maka semakin baik, sedangkan semakin lama atau semakin tidak } \\
\text { tepat waktu pengiriman maka semakin tidak baik. }\end{array}$ \\
\hline & & Lead Time & $\begin{array}{l}\text { Sub kriteria ini terkait dengan semakin cepat lead time } \\
\text { pengiriman maka semakin baik, sedangkan semakin lama lead } \\
\text { time pengiriman maka semakin tidak baik. }\end{array}$ \\
\hline \multirow{2}{*}{2} & \multirow{2}{*}{ Kualitas } & $\begin{array}{l}\text { Spesifikasi } \\
\text { Bahan Baku }\end{array}$ & $\begin{array}{l}\text { Sub kriteria ini terkait dengan semakin tinggi spesifikasi bahan } \\
\text { baku maka semakin baik, sedangkan semakin rendah spesifikasi } \\
\text { bahan baku bahan baku maka semakin tidak baik. }\end{array}$ \\
\hline & & $\begin{array}{l}\text { Jumlah Bahan } \\
\text { Baku }\end{array}$ & $\begin{array}{l}\text { Sub kriteria ini terkait dengan semakin banyak jumlah bahan baku } \\
\text { maka semakin baik, sedangkan semakin sedikit bahan baku maka } \\
\text { semakin tidak baik. }\end{array}$ \\
\hline \multirow{2}{*}{3} & \multirow{2}{*}{ Harga } & $\begin{array}{l}\text { Harga } \\
\text { Pembelian } \\
\text { Bahan Baku }\end{array}$ & $\begin{array}{l}\text { Sub kriteria ini terkait dengan semakin tinggi harga pembelian } \\
\text { bahan baku maka semakin kurang baik, sedangkan semakin } \\
\text { rendah harga bahan baku maka semakin baik. }\end{array}$ \\
\hline & & $\begin{array}{l}\text { Biaya } \\
\text { Transportasi }\end{array}$ & $\begin{array}{l}\text { Sub kriteria ini terkait dengan semakin tinggi biaya transportasi } \\
\text { pembelian bahan baku maka semakin kurang baik, sedangkan } \\
\text { semakin rendah biaya tranportasihbahan baku maka semakin baik. }\end{array}$ \\
\hline
\end{tabular}

Tabel 3. Daftar Alternatif

\begin{tabular}{|c|c|}
\hline No & Alternatif \\
\hline 1 & Manggala Jati \\
\hline 2 & UD. Mukti Jati \\
\hline 3 & Toko Kayu "Mukti" \\
\hline 4 & Gunung Hijau \\
\hline 5 & Indah Sentosa \\
\hline
\end{tabular}

Copyright (C 2018, Kaizen : Management Systems \& Industrial Engineering Journal ISSN 15222-96806 (print), ISSN $155222-95973$ (online) 


\section{KAIZEN : MANAGEMENT SYSTEMS \& INDUSTRIAL ENGINEERING JOURNAL VOL. 3 NO. 2 TEKNIK INDUSTRI UNIVERSITAS PGRI MADIUN}

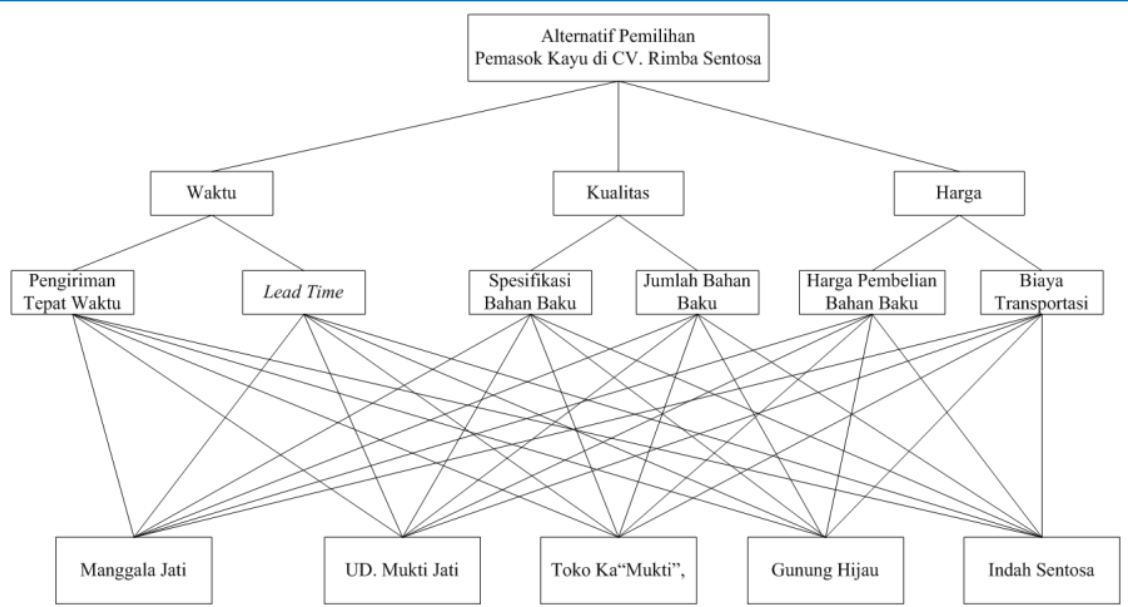

Gambar 1. Struktur Hirarki Alternatif Pemilihan Pemasok

Dari hasil perbandingan berpasangan kuisioner yang diisi oleh para ahli, dapat dihitung nilai konsistensi yang mengandung arti, bahwa pemikiran atau obyek yang serupa dikelompokkan menurut persamaan dan perkaliannya bahwa intensitas relasi antar gagasan atau antar obyek yang didasarkan pada suatu kriteria tertentu akan saling membenarkan secara logis. Tabel 4 menunjukkan perbandingan berpasangan antar kriteria. Tabel 5 menunjukkan normalisasi kriteria. Tabel 6 menunjukkan penentuan vektor bobot kriteria. Tabel 7 menunjukkan penentuan nilai lamda kriteria. Tabel 8 menunjukkan penentuan nilai lamda kriteria lanjutan. Data yang diperoleh dari perhitungan pada Tabel 1 sampai Tabel 8 digunakan untuk menghitung Consistency Index (CI). Perhitungan CI sebagai berikut :

Kriteria $=3$

Consistency Index $(\mathrm{CI}) \quad=\frac{\text { Landa }-\mathrm{n}}{\mathrm{n}-1}=\frac{\mathrm{a}, 02-\mathrm{a}}{\mathrm{a}-1}=0,012$

Consistency Ratio $(\mathrm{CI}) \quad=\frac{C I}{R I}=\frac{0,012}{0,58}=0,021$

Tabel 4. Perbandingan Berpasangan Antar Kriteria

\begin{tabular}{|c|c|c|c|}
\hline & Waktu (K1) & Kualitas (K2) & Harga (K3) \\
\hline Waktu (K1) & 1 & $1 / 5$ & $1 / 4$ \\
\hline Kualitas (K2) & 5 & 1 & 2 \\
\hline Harga (K3) & 4 & $1 / 2$ & 1 \\
\hline Jumlah & 10 & 1,70 & 3,25 \\
\hline
\end{tabular}

Perhitungan:

Waktu $(\mathrm{K} 1)=1+5+4=10$

Kualitas (K2) $=0,20+1+0,50=1,70$

Keandalan $=0,25+2+1=3,25$

Tabel 5. Normalisasi Kriteria

\begin{tabular}{|c|c|c|c|}
\hline & Waktu (K1) & Kualitas (K2) & Harga (K3) \\
\hline Waktu (K1) & 0,10 & 0,12 & 0,08 \\
\hline Kualitas (K2) & 0,50 & 0,59 & 0,62 \\
\hline Harga (K3) & 0,40 & 0,29 & 0,31 \\
\hline Jumlah & 1,00 & 1,00 & 1,00 \\
\hline
\end{tabular}

Perhitungan:

Pada Kriteria Waktu (K1)

Waktu $(\mathrm{K} 1)=1 / 10=0,10$

Kualitas (K2) $=5 / 10=0,50$

$\operatorname{Harga}(\mathrm{K} 3)=4 / 10=0,40$
Pada Kriteria Kualitas (K2)

Waktu $(\mathrm{K} 1)=0,20 / 1,70=0,12$

Kualitas $(\mathrm{K} 2)=1 / 1,70=0,59$

$\operatorname{Harga}(\mathrm{K} 3)=0,50 / 1,70=0,62$
Pada Kriteria Harga (K3)

Kualitas $(\mathrm{K} 2)=0,20 / 3,2=0,08$

$\operatorname{Harga}(\mathrm{K} 3)=2 / 3,25=0,62$

Waktu $(\mathrm{K} 1)=1 / 3,25=0,31$ 


\section{KAIZEN : MANAGEMENT SYSTEMS \& INDUSTRIAL ENGINEERING JOURNAL VOL. 3 NO. 2 TEKNIK INDUSTRI UNIVERSITAS PGRI MADIUN}

Tabel 6. Penentuan Vektor Bobot Kriteria

\begin{tabular}{|c|c|c|c|c|c|}
\hline & Waktu (K1) & Kualitas (K2) & Harga (K3) & Total & Vektor Bobot \\
\hline Waktu (K1) & 0.10 & 0.12 & 0.08 & 0.29 & 0.098 \\
\hline Kualitas (K2) & 0.50 & 0.59 & 0.62 & 1.70 & 0.568 \\
\hline Harga (K3) & 0.40 & 0.29 & 0.31 & 1.00 & 0.334 \\
\hline Total & 1.00 & 1.00 & 1.00 & & 1.000 \\
\hline
\end{tabular}

Pehitungan dari table di atas adalah sebagai berikut:

Nilai Vektor Bobot $=$ Total/ Jumlah Kriteria

Waktu $(\mathrm{K} 1)=(0,10+0,12+0,08) / 3=0,098$

Kualitas $(\mathrm{K} 2) \quad=(0,50+0,59+0,62) / 3=0,568$

Harga $(\mathrm{K} 3) \quad=(0,40+0,29+0,31) / 3=0,334$

Tabel 7. Penentuan Nilai Lamda Kriteria

\begin{tabular}{|c|c|c|c|c|c|c|c|}
\hline & Waktu (K1) & Kualitas (K2) & Harga (K3) & \multirow{4}{*}{$x$} & Vektor Bobot & & \multirow{2}{*}{\begin{tabular}{|c|} 
Perkalian Matrik \\
0.30 \\
\end{tabular}} \\
\hline Waktu (K1) & 1.00 & 0.20 & 0.25 & & 0.098 & & \\
\hline Kualitas (K2) & 5.00 & 1.00 & 2.00 & & 0.568 & $=$ & 1.73 \\
\hline Harga (K3) & 4.00 & 0.50 & 1.00 & & 0.334 & & 1.01 \\
\hline
\end{tabular}

Pehitungan dari tabel di atas adalah sebagai berikut:

$\begin{array}{llll}\text { Waktu }(\mathrm{K} 1) & =(0,10 \times 0,098)+(0,20 \times 0,568)+(0,25 \times 0,334) & =0,30 \\ \text { Kualitas (K2) } & =(5,00 \times 0,098)+(1,00 \times 0,568)+(2,00 \times 0,334) & =1,73 \\ \text { Harga }(\mathrm{K} 3) & =(4,00 \times 0,098)+(0,50 \times 0,568)+(1,00 \times 0,334) & =1,01\end{array}$

Tabel 8. Penentuan Nilai Lamda Kriteria Lanjutan

\begin{tabular}{|c|c|c|c|c|}
\hline & Perkalian Matrik & Total & $=$ & Hasil Pembagian \\
\hline Waktu (K1) & 0.30 & 0.10 & \multirow[b]{4}{*}{$\mathrm{t}$} & 3.01 \\
\hline Kualitas (K2) & 1.73 & 0.57 & & 3.04 \\
\hline Harga $(\mathrm{K} 3)$ & 1.01 & 0.33 & & 3.03 \\
\hline & & & & 3.02 \\
\hline
\end{tabular}

Pehitungan dari tabel di atas adalah sebagai berikut :

$\begin{array}{lll}\text { Waktu (K1) } & =(0,30: 0,10)=3,01 \\ \text { Kualitas (K2) } & =(1,73: 0,57)=3,04 \\ \text { Harga (K3) } & =(1,01: 0,33)=3,03 \\ \quad \mathrm{t} & =1 / 3 \times(3,01+3,04+3,03)=3,02\end{array}$

Pada perhitungan $\mathrm{CR}$ diperoleh $\leq 0,1$ maka penilaian konsisten dan data dapat dilanjutkan ke perhitungan selanjutnya. Perhitungan CR dilakukan untuk semua perbandingan berpasangan. Berdasarkan hasil perhitungan CR atau uji konsistensi diperoleh rekapitulasi pada Tabel 9 dan Tabel 10. Hasil Tabel 9 menunjukkan nilai bobot kriteria. Hasil Tabel 10 menunjukkan nilai bobot sub kriteria. Penilaian dari sub kriteria sebagai berikut :

Rumus

Pengiriman Tepat Waktu (SK11)

Lead Time (SK12)

Spesifikasi Bahan Baku (SK21)

Jumlah Bahan Baku (SK22)

Harga Pembelian Bahan Baku (SK31)

Biaya Transportasi (SK32)
$=$ Bobot Kriteria $\times$ Bobot Sub Kriteria

$=(0,098 \times 0,167)=0,016$

$=(0,098 \times 0,833)=0,082$

$=(0,568 \times 0,750)=0,426$

$=(0,568 \times 0,250)=0,142$

$=(0,334 \times 0,833)=0,278$

$=(0,334 \times 0,167)=0,056$

Tabel 9. Nilai Bobot Kriteria

\begin{tabular}{|c|c|c|c|}
\hline No & Kriteria & Kode & Nilai Bobot Kriteria \\
\hline 1 & Waktu & K1 & 0,098 \\
\hline 2 & Kualitas & K2 & 0,568 \\
\hline 3 & Harga & K3 & 0,334 \\
\hline
\end{tabular}

Copyright (C) 2018, Kaizen : Management Systems \& Industrial Engineering Journal ISSN 15222-96806 (print), ISSN $155222-95973$ (online) 


\section{KAIZEN : MANAGEMENT SYSTEMS \& INDUSTRIAL ENGINEERING JOURNAL VOL. 3 NO. 2 TEKNIK INDUSTRI UNIVERSITAS PGRI MADIUN}

Tabel 10. Nilai Bobot Sub Kriteria

\begin{tabular}{|c|c|l|c|c|}
\hline No & Kriteria & \multicolumn{1}{|c|}{ Sub Kriteria } & Kode & Nilai Bobot Sub Kriteria \\
\hline \multirow{2}{*}{1} & \multirow{2}{*}{ Waktu } & Pengiriman Tepat Waktu & SK11 & 0,167 \\
\cline { 3 - 5 } & & Lead Time & SK12 & 0,833 \\
\hline \multirow{2}{*}{2} & \multirow{2}{*}{ Kualitas } & Spesifikasi Bahan Baku & SK21 & 0,750 \\
\cline { 3 - 5 } & \multirow{2}{*}{3} & Jumlah Bahan Baku & SK22 & 0,250 \\
\hline \multirow{2}{*}{ Harga } & Harga Pembelian Bahan Baku & SK31 & 0,833 \\
\cline { 3 - 5 } & & Biaya Transportasi & SK32 & 0,167 \\
\hline
\end{tabular}

Setelah dilakukan perhitungan bobot akhir maka selanjutnya adalah melakukan perhitungan nilai alternatif dengan melakukan perkalian antara nilai bobot akhir dengan nilai alternatif pada masing-masing sub kriteria. Hasil perhitungan dapat dilihat pada Tabel 11 dan Tabel 12. Berdasarkan dari perhitungan pada Tabel 11 dan Tabel 12 diperoleh hasil bahwa nilai masing-masing alternatif berdasarkan nilai tertinggi adalah "Indah Sentosa" mempunyai nilai 0,344 atau 34,420\%. Selanjutnya adalah "Toko Kayu "Mukti"” mempunyai nilai 0,184 atau 18,426\%. Selanjutnya adalah "Gunung Hijau" mempunyai nilai 0,184 atau 18,426\%. Selanjutnya adalah "Manggala Jati" mempunyai nilai 0,178 atau 17,381\%. Selanjutnya adalah "UD. Mukti Jati" mempunyai nilai 0,109 atau 10,922\%. Sehingga diperoleh kesimpulan bahwa pemasok terbaik adalah "Indah Sentosa.

Tabel 11. Nilai Alternatif ditinjau dari Masing-Masing Sub Kriteria

\begin{tabular}{|c|c|c|c|c|c|c|c|c|}
\hline \multirow{4}{*}{ No } & \multirow{4}{*}{ Alternatif } & \multirow{4}{*}{ 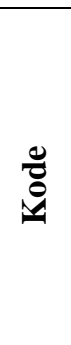 } & \multirow{2}{*}{\multicolumn{2}{|c|}{$\begin{array}{c}\text { Waktu (K1) } \\
0,098\end{array}$}} & \multirow{2}{*}{\multicolumn{2}{|c|}{$\begin{array}{c}\text { Kualitas (K2) } \\
\mathbf{0 , 5 6 8} \\
\end{array}$}} & \multirow{2}{*}{\multicolumn{2}{|c|}{$\begin{array}{c}\text { Harga }(\mathrm{K3}) \\
\mathbf{0 , 3 3 4} \\
\end{array}$}} \\
\hline & & & & & & & & \\
\hline & & & 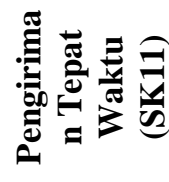 & 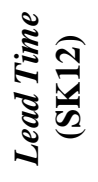 & 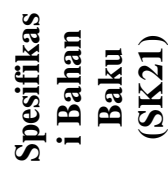 & 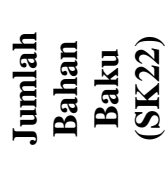 & 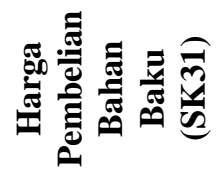 & 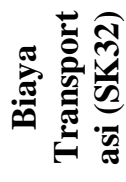 \\
\hline & & & 0,167 & 0,833 & 0,750 & 0,250 & 0,833 & 0,167 \\
\hline 1 & Manggala Jati & A1 & 0,097 & 0,503 & 0,120 & 0,039 & 0,177 & 0,533 \\
\hline 2 & UD, Mukti Jati & A2 & 0,439 & 0,035 & 0,085 & 0,237 & 0,084 & 0,108 \\
\hline 3 & $\begin{array}{l}\text { Toko Kayu } \\
\text { "Mukti" }\end{array}$ & A3 & 0,290 & 0,134 & 0,041 & 0,159 & 0,425 & 0,186 \\
\hline 4 & Gunung Hijau & A4 & 0,134 & 0,068 & 0,215 & 0,488 & 0,042 & 0,064 \\
\hline 5 & Indah Sentosa & A5 & 0,041 & 0,260 & 0,539 & 0,077 & 0,273 & 0,108 \\
\hline
\end{tabular}

Tabel 12. Hasil Perhitungan Metode AHP

\begin{tabular}{|c|l|c|c|c|c|}
\hline No & \multicolumn{1}{|c|}{ Alternatif } & Kode & Nilai AHP & Persentase & Ranking AHP \\
\hline 1 & Manggala Jati & A1 & 0,178 & $17,831 \%$ & 4 \\
\hline 2 & UD. Mukti Jati & A2 & 0,109 & $10,922 \%$ & 5 \\
\hline 3 & Toko Kayu "Mukti" & A3 & 0,184 & $18,426 \%$ & 2 \\
\hline 4 & Gunung Hijau & A4 & 0,184 & $18,402 \%$ & 3 \\
\hline 5 & Indah Sentosa & A5 & 0,344 & $34,420 \%$ & 1 \\
\hline
\end{tabular}

Simpulan

Berdasarkan pengolahan data dan analisis data yang telah dilakukan pada bab sebelumnya maka kesimpulan yang dapat diambil adalah Kriteria-kriteria yang dapat digunakan untuk penilaian kinerja pemasok adalah waktu, kualitas, dan harga. Sub kriteria yang dapat digunakan dalam untuk penilaian kinerja pemasok adalah pengiriman tepat waktu, lead time, spesifikasi bahan baku, jumlah bahan baku, harga pembelian bahan baku, dan biaya transportasi. Berdasarkan perhitungan dengan menggunakan metode AHP, maka pemasok yang mempunyai nilai terbaik adalah pemasok "Indah Sentosa", yang mana nilainya adalah 0,344 atau 34,420 \% .

Copyright (C) 2018, Kaizen : Management Systems \& Industrial Engineering Journal ISSN 15222-96806 (print), ISSN 155222-95973 (online) 


\section{Daftar Pustaka}

[1] I. N. Pujawan, Supply Chain Management. Surabaya: Guna Widya, 2015.

[2] M. Rahardjo, Studi Kasus dalam Penelitian Kualitatif: Konsep dan Prosedurnya. Malang, 2017.

[3] K. Amin, J. Krishnan, and J. S. Yang, "Going Concern Opinion and Cost of Equity," Audit. A J. Pract. Theory, vol. 33, no. 4, pp. 1-39, 2014.

[4] C. O. Doaly, P. Moengin, and G. Chandiawan, "Pemilihan Multi-Kriteria Pemasok Department Store Menggunakan Metode Fuzzy Ahp Dan Topsis," J. Ilm. Tek. Ind., vol. 7, no. 1, pp. 70-78, 2019.

[5] L. Utari and R. Agustriani, "Penerapan Metode Simple Additive Weighting Untuk Merekomendasikan Penentuan Supplier Bahan Baku Kertas," Teknois J. Ilm. Teknol. Inf. dan Sains, vol. 9, no. 1, pp. 43-52, 2019.

[6] C. Trimulia, S. Defit, and G. W. Nurcahyo, "Pemilihan Supplier Obat yang Tepat dengan Metode Simple Additive Weighting," J. Sains dan Teknol. Ind., vol. 16, no. 1, p. 37, 2018.

[7] S. O. Viarani and H. R. Zadry, "Analisis Pemilihan Pemasok dengan Metode Analitycal Hierarchy Process di Proyek Indarung VI PT Semen Padang,” J. Optimasi Sist. Ind., vol. 14, no. 1, p. 55, 2016.

[8] F. Saputra, A. Bakar, and F. H. Mustofa, "Usulan Penentuan Prioritas Supplier Bahan Baku Plate Steel dengan Metode Promethee di PT DIRGANTARA INDONESIA,”J. Itenas, vol. 4, no. 1, pp. 370-381, 2016. 